\title{
Prediksi Kebutuhan Tempat Tidur Pasien COVID-19 di Rumah Sakit Umum Daerah dr. Wahidin Sudiro Husodo Kota Mojokerto (Juni 2021-Juli 2022)
}

\section{Prediction of Bed Needs for COVID-19 Patients at the Regional General Hospital (RSUD) of dr. Wahidin Sudiro Husodo, Mojokerto City (June 2021-July 2022)}

\author{
Maulida Citra Devi ${ }^{1}$, Forman Novrindo Sidjabat ${ }^{2 *}$ \\ ${ }^{1,2}$ Fakultas Teknologi dan Manajemen Kesehatan, Institut Ilmu Kesehtan Bhakti Wiyata \\ Kediri \\ Jl. KH. Wachid Hasyim No.65, Gedung Adipadma, Kota Kediri \\ *e-mail korespondensi: sidjabat.fn@iik.ac.id
}

\begin{abstract}
Abstrak
Pandemi COVID-19 berdampak besar pada banyak rumah sakit mulai Maret 2020. Secara global, rumah sakit perlu menyiapkan ruangan dengan kapasitas yang memadai sesuai kebutuhan pasien COVID-19. Salah satu indikator untuk menilai peningkatan permintaan pelayanan rumah sakit pada masa pandemi dapat dilihat dari nilai Bed Occupancy Rate. Nilai BOR RSUD dr. Wahidin Sudirohusodo pada periode April 2020-Mei 2021 berada di bawah standar. Penelitian ini bertujuan untuk memprediksi kebutuhan tempat tidur pasien COVID-19 di RSUD dr. Wahidin Sudiro Husodo Mojokerto untuk periode Juni 2021-Juli 2022. Penelitian ini menggunakan penelitian deskriptif dengan pendekatan retrospektif Subyek penelitian adalah data rekapitulasi pasien COVID-19 menggunakan teknik observasi dengan mencatat jumlah tempat tidur dan jumlah hari rawat inap pasien COVID-19 periode April 2020-Mei 2021. Analisis data dilakukan dengan menggunakan fungsi linear least squares dan diprediksi menggunakan nilai BOR 60\%, 70\% dan 80\%. Kebutuhan tempat tidur pasien COVID-19 di RSUD dr. Wahidin Sudiro Husodo Mojokerto periode Juni 2021-Juli 2022 (BOR 60\%: 40-65 tempat tidur, 70\%: 34-56 tempat tidur, 85\%: 28-46 tempat tidur) di bawah jumlah tempat tidur yang telah dialokasikan oleh rumah sakit untuk pengiriman layanan COVID 19 (16-81 tempat tidur). Kelebihan tempat tidur untuk merawat pasien COVID-19 dapat menjadi dasar bagi manajemen rumah sakit untuk meninjau pengadaan dan penempatan tempat tidur yang sesuai.
\end{abstract}

Kata kunci: Bed occupation ratio, COVID-19, kebutuhan tempat tidur

\begin{abstract}
The COVID-19 pandemic has had a major impact on many hospitals starting in March 2020. Globally, hospitals are need to prepare rooms with adequate capacity according to the needs of COVID-19 patients. One indicator to assess the increasing demand for hospital services during the pandemic can be seen by the value of the Bed Occupancy Rate. BOR value of RSUD dr. Wahidin Sudirohusodo in the April 2020May 2021 period was below the standard. This study aims to predict the bed needs of COVID-19 patients at the RSUD dr. Wahidin Sudiro Husodo Mojokerto for the period June 2021-July 2022. This study uses a descriptive study with a retrospective approach. The subject of the study was recapitulation data for COVID-19 patients using observation techniques by recording the number of beds and the number of days hospitalized for COVID-19 patients for the April 2020-May 2021 period. Data analysis was carried out using the least squares linear trend function and predicted using a BOR value of $60 \%, 70 \%$ and $80 \%$.
\end{abstract}

p-ISSN: | e-ISSN: 2807-2596

website: ijhim.stikesmhk.ac.id/index.php/ 
The need for beds for COVID-19 patients at the RSUD dr. Wahidin Sudiro Husodo Mojokerto for the period June 2021-July 2022 (BOR 60\%: 40-65 beds, 70\%: 34-56 beds, 85\%: 28-46 beds) below the number of beds that have been allocated by the hospital for the delivery of COVID- services 19 (16-81 beds). The excess of beds for treating COVID-19 patients can be the basis for hospital management to review the procurement and placement of appropriate beds.

Keywords: Bed occupation ratio, COVID-19, beds need

\section{PENDAHULUAN}

Pandemi COVID- 19 telah memberikan dampak besar bagi banyak rumah sakit mulai Maret 2020. Rumah Sakit secara global perlu menyiapkan ruangan dengan kapasitas yang memadai sesuai dengan kebutuhan kunjungan ODP/PDP serta pasien terkonfirmasi COVID 19. Untuk memperisapkan sistem perawatan kesehatan, hal penting yang perlu dilakukan adalah kesiapan organisasi dan perencanaan kapasitas tempat tidur (Leung et al., 2020). Perencanaan kapasitas rumah sakit didorong oleh dinamika yang kompleks antara input, output dan jumlah tempat tidur yang tersedia (Kuntz, Scholtes dan Vera, 2007; Yi et al., 2010).

Pada waktu normal, rumah sakit bertujuan untuk mencapai hunian tempat tidur yang optimal dengan memaksimalkan hunian tempat tidur sambil meminimalkan overflow, namun dimasa pandemi masuknya pasien tidak terduga dan secara tiba-tiba yang dapat menyebabkan terbatasnya kapasitas tempat tidur dan tidak efisennya penggunaan tempat tidur (Litvak et al., 2008). Kurangnya kapasitas tempat tidur, kelangkaan persediaan dan tingkat hunian yang tinggi akan menyebabkan bertambahnya beban rumah sakit. Untuk mencegah limpahan tersebut, sistem perawatan kesehatan dapat mengambil beberapa langkah. Salah satu langkah yang diambil Pemerintah Indonesia adalah dengan mengharuskan rumah sakit mengkonversikan 20 hingga 40 persen tempat tidur yang dimiliki untuk perawatan rawat inap pasien COVID-19 (RI, 2021). Dengan begitu, rumah sakit dapat mempertahankan mutu pelayanan yang diberikan pada seluruh pasien yang ditunjukkan dari tercapainya kepuasan pasien (Sabarguna, 2008). Pengelolaan tempat tidur pasien merupakan aspek yang mendukung tercapainya mutu pelayanan rumah sakit sehingga membutuhkan perhatian besar dari manajemen rumah sakit untuk mengevaluasi efisiensi penggunaan tempat tidur untuk masingmasing kelas unit rawat inap (Lolita, 2016). Selain pergeseran tempat tidur reguler ke tempat tidur khusus COVID-19 pengendalian kasus COVID-19 di rumah sakit dapat dilakukan dengan langkahlangkah membiasakan perilaku kebersihan personal khusus, dan memperkirakan kapasitas yang memadai di Unit Perawatan Intensif (ICU) (RI, 2021). Sekitar 9 hingga 11 persen pasien COVID-19 yang dirawat membutuhkan tindakan pendukung lain seperti tenaga kesehatan terlatih, peralatan pemantauan, ventilator dan ruangan ICU (Remuzzi dan Remuzzi, 2020). Salah satu indikator untuk menilai peningkatan kebutuhan pelayanan rumah sakit di masa pandemi dapat dilihat dengan nilai Bed Occupancy Rate yang dihitung berdasarkan jumlah tempat tidur, periode waktu (yaitu satu tahun) dan jumlah total hari rawat inap (yaitu jumlah hari keseluruhan semua pasien dirawat di rumah sakit) (Pecoraro et al., 2015).

Rumah Sakit Umum Daerah dr. Wahidin Sudiro Husodo Kota Mojokerto merupakan rumah sakit rujukan COVID19 mulai April Tahun 2020. Berdasarkan survey awal didapatkan rata-rata jumlah kunjungan pasien COVID-19 pada periode April 2020-Mei 2021 adalah sebanyak 850 kunjungan pasien. Pada bulan April 2020 nilai BOR sebesar $13.75 \%$, bulan Mei 
sebesar $38.10 \%$, bulan Juni sebesar $58.04 \%$, bulan Juli sebesar $109.30 \%$, pada bulan Agustus sebesar 48.65\%, bulan September sebesar $29.89 \%$, bulan Oktober sebesar $37.89 \%$, bulan November sebesar $58.94 \%$, bulan Desember sebesar $87.10 \%$, pada bulan Januari 2021 sebesar $75.51 \%$, bulan Februari sebesar 51.41\%, pada bulan Maret sebesar 59.23\%, pada bulan April sebesar $39.27 \%$ dan bulan Mei sebesar $17.41 \%$. BOR periode April 2020-Mei 2021 rata-rata belum memenuhi standar ideal BOR Depkes yaitu 60-85\%. Penggunaan tempat tidur untuk pasien COVID-19 di RSUD dr. Wahidin Sudiro Husodo Kota Mojokerto belum efisien karena ketersediaan tempat tidur melebihi permintaan, maka peneliti tertarik memprediksi kebutuhan tempat tidur yang dapat digunakan sebagai bahan perencanaan dan evaluasi.

\section{METODE PENELITIAN}

Jenis penelitian yang digunakan
adalah jenis penelitian deskriptif
menggunakan pendekatan retrospektif.
Penelitian menggunakan seluruh data
rekapitulasi rawat inap pasien COVID-19
periode April 2020-Mei 2021 yang tersedia
di RSUD dr. Wahidin Sudiro Husodo Kota.
Data diambil menggunakan lembar
observasi yang kemudian dilakukan
pengolahan data menggunakan fungsi
trend linear kuadrat terkecil (least square)
pada microsoft excel.

dengan rumus prediksi $\mathrm{Y}=\mathrm{a}+\mathrm{bX}$

Keterangan:

$\mathrm{Y}=$ nilai trend (forecast) / nilai yang akan diramalkan $\mathrm{a}=$ bilangan konstan

$\mathrm{b}=$ slope/koefisien kecondongan garis trend

$\mathrm{X}=$ kode tahun.

dan, Rumus BOR $=\frac{\sum H P}{\sum \mathrm{TT} \times \mathrm{t}} \times 100 \%$

Keterangan:

$\mathrm{HP}=$ Jumlah hari perawatan

TT $=$ Jumlah tempat tidur

$\mathrm{t}=$ Periode waktu (hari efektif)

Analisa dan penyajian hasil pada penelitian ini ditampilkan dalam bentuk tabel dan narasi deskriptif. Penelitian ini telah lolos kaji etik dari Komite Etik Penelitian Kesehatan (KEPK) RSUD Dr.Wahidin Sudiro Husodo Kota Mojokerto dengan nomor 06/KEPKRSWH/EA//2021.

\section{HASIL DAN PEMBAHASAN}

Pada periode April 2020-Mei 2021 khusus pasien COVID-19 yang mendapatkan perawatan di RSUD dr. Wahidun Sudiro Husodo tertinggi tercatat pada bulan Januari 2021 sebanyak 331 pasien dan kunjungan pasien terendah terdapat pada bulan April 2020 sebanyak 12 pasien. Sementara, alokasi tempat tidur untuk pasien COVID-19 sebanyak 16-81 buah. Terbanyak pada bulan Januari 2021Februari 2021 (81 buah tempat tidur) dan jumlah tempat tidur paling sedikit terdapat pada bulan April 2020-Mei 2020 (16 buah tempat tidur). Hari perawatan tertinggi terdapat pada bulan Januari 2021 sebanyak 1896 hari dan hari perawatan terendah terdapat pada bulan April 2020 sebanyak 66 hari.

Tabel 1. Jumlah Tempat Tidur, Jumlah Hari Perawatan, Jumlah Kunjungan Pasien COVID-19 di RSUD Dr. Wahidin Sudiro Husodo Kota Mojokerto Periode April 2020-Mei 2021

\begin{tabular}{llrrrr} 
No & Bulan-Tahun & $\sum$ TT & $\sum$ HP & $\sum$ KP & $\sum$ HE \\
\hline 1 & April-2020 & 16 buah & 66 hari & 12 pasien & 30 hari \\
\hline
\end{tabular}

p-ISSN:

| e-ISSN: 2807-2596

website: ijhim.stikesmhk.ac.id/index.php/ 


\begin{tabular}{|c|c|c|c|c|c|}
\hline No & Bulan-Tahun & $\sum \mathrm{TT}$ & $\sum \mathbf{H P}$ & $\sum \mathbf{K P}$ & $\sum \mathbf{H E}$ \\
\hline 2 & Mei-2020 & 16 buah & 189 hari & 15 pasien & 31 hari \\
\hline 3 & Juni-2020 & 34 buah & 592 hari & 65 pasien & 31 hari \\
\hline 4 & Juli-2020 & 34 buah & 1152 hari & 108 pasien & 30 hari \\
\hline 5 & Agustus-2020 & 61 buah & 920 hari & 98 pasien & 31 hari \\
\hline 6 & September-2020 & 61 buah & 547 hari & 121 pasien & 30 hari \\
\hline 7 & Oktober-2020 & 63 buah & 740 hari & 154 pasien & 31 hari \\
\hline 8 & November-2020 & 63 buah & 1114 hari & 234 pasien & 31 hari \\
\hline 9 & Desember-2020 & 63 buah & 1701 hari & 296 pasien & 28 hari \\
\hline 10 & Januari-2021 & 81 buah & 1896 hari & 331 pasien & 31 hari \\
\hline 11 & Februari-2021 & 81 buah & 1166 hari & 240 pasien & 30 hari \\
\hline 12 & Maret-2021 & 50 buah & 918 hari & 227 pasien & 31 hari \\
\hline 13 & April-2021 & 50 buah & 589 hari & 166 pasien & 30 hari \\
\hline 14 & Mei-2021 & 58 buah & 313 hari & 63 pasien & 31 hari \\
\hline
\end{tabular}

Sumber: Data Rekapitulasi Sensus Harian Rawat Inap Pasien COVID-19 di RSUD Dr. Wahidin Sudiro Husodo Kota Mojokerto Periode April 2020-Mei 2021

Ket: TT: Tempat Tidur, HP: Hari Perawatan, KP: Kunjungan Pasien, HE: Hari Efektif

\section{Prediksi Hari Perawatan Pasien COVID-19 di RSUD Dr.Wahidin Sudiro Husodo Kota Mojokerto Periode Juni 2021-Juli 2022}

Untuk dapat memprediksi kebutuhan tempat tidur, hal pertama yang perlu dilakukan adalah memprediksi jumlah hari perawatan periode Juni 2021Juli 2022. Menggunakan data observasi di atas, maka prediksi jumlah hari perawatan dapat dihitung menggunakan peramalan regresion linear (least square) yang biasa dikenal dengan istilah analisis trend, sebagai berikut:

a. Mengetahui jumlah Hari Perawatan dan menentuan nilai $\mathrm{X}$ dan $\mathrm{Y}$ b. Menentukan nilai a dan $b$ dengan menggunakan rumus: $\mathrm{a}=\frac{\sum \mathrm{Y}}{\mathrm{n}}$, dan

$$
\begin{array}{rlrl}
\mathrm{b}=\frac{\sum \mathrm{XY}}{\mathrm{X}^{2}} & & \\
\mathrm{a} & =\frac{\sum \mathrm{Y}}{\mathrm{n}} & \mathrm{b} & =\frac{\sum \mathrm{XY}}{\mathrm{X}^{2}} \\
\mathrm{a} & =\frac{\sum 11903}{14} & \mathrm{~b} & =\frac{\sum 19359}{910} \\
\mathrm{a} & =850 & \mathrm{~b} & =21,27
\end{array}
$$

c. Menghitung $\mathrm{Y}=\mathrm{a}+\mathrm{bX}$, dengan nilai $\mathrm{X}$ adalah 15 (interval 2 setelah nilai $X$ pada bulan terakhir (Mei-2021)), sehingga persamaan untuk memprediksi hari perawatan Juni-2021 hingga Juli-20211 adalah $\mathrm{Y}=$

\begin{tabular}{|c|c|c|c|c|c|c|c|}
\hline \multirow{2}{*}{ No } & \multirow{2}{*}{ Bulan-Tahun } & \multirow{2}{*}{$\begin{array}{c}\text { Y } \\
\text { (Hari } \\
\text { Perawatan } \\
\text { periode lampau) }\end{array}$} & \multirow{2}{*}{$\mathbf{X}$} & \multirow{2}{*}{$\mathbf{X Y}$} & \multirow{2}{*}{$\mathbf{X}^{2}$} & \multicolumn{2}{|c|}{$\begin{array}{l}\text { Prediksi Hari Perawatan } \\
\text { (Juni-2021 - Juli-2022) }\end{array}$} \\
\hline & & & & & & Bulan-Tahun & Hari \\
\hline 1 & April-2020 & 66 & -13 & -858 & 169 & Juni-2021 & 1169 \\
\hline 2 & Mei-2020 & 189 & -11 & -2079 & 121 & Juli-2021 & 1123 \\
\hline 3 & Juni-2020 & 592 & -9 & -5328 & 81 & Agustus -2021 & 1048 \\
\hline 4 & Juli-2020 & 1152 & -7 & -8064 & 49 & September -2021 & 992 \\
\hline 5 & Agustus-2020 & 920 & -5 & -4600 & 25 & Oktober -2021 & 1003 \\
\hline
\end{tabular}
$850+21,27(15)$

Tabel 2. Prediksi Hari Perawatan Pasien COVID-19 di RSUD Dr.Wahidin Sudiro Husodo Kota Mojokerto Periode Juni 2021-Juli 2022 


\begin{tabular}{clrrrrll}
\hline 6 & September-2020 & 547 & -3 & -1641 & 9 & November -2021 & 982 \\
7 & Oktober-2020 & 740 & -1 & -740 & 1 & Desember -2021 & 887 \\
8 & November-2020 & 1114 & 1 & 1114 & 1 & Januari -2022 & 748 \\
9 & Desember-2020 & 1701 & 3 & 5103 & 9 & Februari -2022 & 713 \\
10 & Januari-2021 & 1896 & 5 & 9480 & 25 & Maret -2022 & 735 \\
11 & Februari-2021 & 1166 & 7 & 8162 & 49 & April -2022 & 831 \\
12 & Maret-2021 & 918 & 9 & 8262 & 81 & Mei-2022 & 864 \\
13 & April-2021 & 589 & 11 & 6479 & 121 & Juni-2022 & 871 \\
14 & Mei-2021 & 313 & 13 & 4069 & 169 & Juli-2022 & 827 \\
& Jumlah & 11903 & 0 & 19359 & 910 & & \\
\hline
\end{tabular}

Hasil perhitungan prediksi jumlah hari perawatan pasien COVID-19 di RSUD Dr.Wahidin Sudiro Husodo Kota Mojokerto Periode Juni 2021-Juli 2022 mengalami kondisi yang fluktuatif. Hari perawatan terus menurun setelah Juli 2021 (1169 hari) hingga September-2021 (992 hari) kemudian meningkat kembali pada Oktober-2021 (1003 hari) namun kembali turun pada November-2021 (982 hari) hingga meningkat kemali pada April-2022 (831 hari) dan pada Juli-2022 mengalami penurunan hari perawatan (827 hari).

\section{Prediksi Kebutuhan Tempat Tidur Pasien COVID-19 di RSUD Dr. Wahidin Sudiro Husodo Kota Mojokerto Periode Juni 2021-Juli 2022}

Prediksi Kebutuhan tempat tidur pasien COVID-19 di RSUD Dr. Wahidin Sudiro Husodo Kota Mojokerto periode Juni 2021-Juli 2022 dihitung menggunakan standar ideal BOR Depkes 60\%, 70\% dan $85 \%$. Perhitungan prediksi dengan rumus BOR menggunakan komponen hasil prediksi hari perawatan periode Juni 2021Juli 2022 dan hari efektif kalender masehi.

a. Perhitungan kebutuhan tempat tidur Juni-2021 mengunakan standar minimal BOR Depkes yaitu $60 \%$ sebagai berikut:

$$
\begin{aligned}
60 & =\frac{\sum 1169}{\sum \mathrm{TT} \times 30} \times 100 \% \\
\mathrm{TT} & =\frac{\sum 1169}{60 \% \times 30} \times 100 \% \\
\mathrm{TT} & =65 \text { buah }
\end{aligned}
$$

b. Perhitungan kebutuhan tempat tidur Juni-2021 menggunakan standar BOR Depkes yaitu $70 \%$ sebagai berikut:

$$
\begin{aligned}
& 70 \%=\frac{\sum 1169}{\sum \mathrm{TT} \times 30} \times 100 \% \\
& \mathrm{TT}=\frac{\sum 1169}{70 \% \times 30} \times 100 \% \\
& \mathrm{TT}=56 \text { buah }
\end{aligned}
$$

c. Perhitungan kebutuhan tempat tidur Juni-2021 menggunakan standar maksimal BOR Depkes yaitu $85 \%$ sebagai berikut:

$$
\begin{aligned}
85 & =\frac{\sum 1169}{\sum \mathrm{TT} \times 30} \times 100 \% \\
\mathrm{TT} & =\frac{\sum 1169}{85 \% \times 30} \times 100 \% \\
\mathrm{TT} & =46 \text { buah }
\end{aligned}
$$

Perhitungan dengan rumus yang sama dilakukan untuk bulan yang diprediksi selanjutnya, dengan hasil prediksi menunjukkan kebutuhan tempat tidur dimasa depan berada direntang jumlah tempat tidur yang telah dialokasikan rumah sakit (16-81 tempat tidur), yang ditampilkan pada tabel 3 berikut. 
6 Indonesian Journal of Health Information Management (IJHIM), Vol. 2 No. 1 (2022),

Tabel 3. Prediksi Kebutuhan Tempat Tidur Pasien COVID-19 di RSUD Dr. Wahidin Sudiro Husodo Kota Mojokerto Periode Juni 2021-Juli 2022

\begin{tabular}{clccc}
\hline \multirow{2}{*}{ No } & \multirow{2}{*}{ Bulan-Tahun } & \multicolumn{2}{c}{ Prediksi Kebutuhan Tempat Tidur } \\
\cline { 3 - 5 } & & BOR 60\% & BOR 70\% & BOR 85\% \\
\hline 1 & Juni-2021 & 65 buah & 56 buah & 46 buah \\
2 & Juli-2021 & 60 buah & 52 buah & 43 buah \\
3 & Agustus -2021 & 56 buah & 48 buah & 40 buah \\
4 & Sepember-21 & 55 buah & 47 buah & 39 buah \\
5 & Oktober -2021 & 54 buah & 46 buah & 38 buah \\
6 & November-21 & 55 buah & 47 buah & 39 buah \\
7 & Desember -2021 & 48 buah & 41 buah & 34 buah \\
8 & Januari -2022 & 42 buah & 36 buah & 30 buah \\
9 & Februari -2022 & 42 buah & 36 buah & 30 buah \\
10 & Maret -2022 & 40 buah & 34 buah & 28 buah \\
11 & Apr-22 & 46 buah & 40 buah & 33 buah \\
12 & Mei-2022 & 46 buah & 40 buah & 33 buah \\
13 & Juni-2022 & 48 buah & 41 buah & 34 buah \\
14 & Juli-2022 & 44 buah & 38 buah & 31 buah \\
\hline
\end{tabular}

Penyebaran global yang cepat dari COVID-19 pada dalam kurun satu setengah tahun telah mendorong pelayanan kesehatan melakukan respon cepat. Tidak hanya melakukan kegiatan surveilans epidemiologi pada level komunitas, salah satu tindakan respon cepat terhadap wabah COVID-19 adalah peningkatan kemampuan layanan kesehatan memenuhi peningkatan permintaan akan perawatan klinis (WHO Regional Office for Europe, 2020; Sidjabat dan Arthameivia, 2021). Ketersediaan tempat tidur dan efisiensi pengelolaan sumber daya kesehatan di rumah sakit berperan penting untuk menentukan ruangan bagi pasien jika terjadi situasi darurat, seperti COVID-19. pengurangan sumber daya rumah sakit baru-baru ini mungkin berdampak pada fungsi rumah sakit dan efisiensi dalam pengelolaan kasus klinis (Ravaghi et al., 2020). Efisiensi perawatan kasus klinis COVID-19 dapat digambarkan dari manajemen tempat tidur dan evaluasi kinerja profesional kesehatan menangani pasien di rumah sakit (Tortorella et al., 2013; Hashjin et al., 2014; Levaggi dan
Montefiori, 2014; Pecoraro et al., 2016; Han, Chen dan Li, 2018).

Arus masuk pasien COVID-19 di rumah sakit dapat disebabkan beberapa hal, pada penelitian ini ditemukan peningkatan kasus COVID-19 yang ditangai RSUD dr. Wahidin Sudirohusodo yang fluktuatif. Dapat digambarkan kenaikan terjadi pada waktu-waktu tertentu seperti peningkatan kasus setelah peningkatan mobilitas masyarakat hari besar Nasional salah satunya lebaran pada bulan Mei 2020, sehingga pada bulan Juni 2020 kasus COVID-19 mengalami peningkatan 5 kali lipat dan bulan Juli 2020 meningkat 2 kali lipat. Tren ini sesuai dengan analisis data COVID-19 nasional per tanggal 26 Juli 2020 bahwa Provinsi Jawa Timur termasuk dalam 5 besar provinsi dengan jumlah kasus tertinggi sebanyak 20.539 kasus dan Kota Mojokerto menduduki nomor kedua dengan laju insiden tertinggi sebanyak 150.42 kasus per 100.000 penduduk (Provinsi Jawa Timur, 2020). Kasus COVID-19 kembali meningkat mulai bulan Oktober 2020 dan puncaknya terjadi pada bulan Januari 2021 yang sebelumnya terdapat hari libur panjang natal dan tahun 
baru. Tren analisis data COVID-19 per 31 Januari 2021 Kota Mojokerto termasuk dalam 3 besar Insiden Kumulatif Tertinggi dengan menduduki nomor pertama sebanayak 1417.45 kasus per 100.000 peduduk (Provinsi Jawa Timur, 2020). Terdapat dua penyebab COVID-19 tinggi pada bulan Juli di Jawa Timur yaitu rendahnya tingkat kepatuhan masyarakat terhadap protokol kesehatan dan lemahnya kebijakan dengan penegakan sanksi tegas terkait pembatasan mobilitas dan aktivitas sosial masyarakat di zona merah dan zona oranye (Suara.com, 2020).

Arus peningkatan pasien dikarenakan layanan kesehatan yang diterima pasien COVID 19 dibayarkan oleh pemerintah, walaupun demikian mereka yang berada di negara dengan sistem perawatan kesehatan campuran atau swasta mungkin lebih kecil kemungkinannya untuk mencari perawatan karena ketidakmampuan untuk membayar layanan(Peters et al., 2008). Literatur sebelumnya telah menunjukkan bahwa mereka yang memiliki asuransi kesehatan lebih cenderung mencari perawatan, dibandingkan dengan yang tidak memiliki asuransi (Peters et al., 2008).

Peningkatan pasien di rumah sakit juga disebabkan adanya pasien dengan komorbiditas, beberapa penelitian menemukan masyarakat dengan komorbiditas memiliki ketakutan lebih tinggi dimasa pandemi sehingga akan mencari perawatan medis darurat (Woolf et al., 2020). Informasi adanya gelombang kedua, perubahan varian virus dan efek musiman influenza menyebabkan semakin banyak pencarian pengobatan oleh masyarakat yang merasa memiliki gejala (Bloom, Foroutanjazi dan Chatterjee, 2020; Xu dan Li, 2020; Iftimie et al., 2021).

Penelitian ini mendapatkan pada bulan Maret 2021 pasien COVID-19 mengalami penurunan sehingga terjadi pengurangan jumlah tempat tidur. Penurunan terjadi secara global di semua kawasan mulai dari kawasan dengan kasus tertinggi seperti Amerika dan Eropa, dari semula puncaknya pada Januari 2021 (Satuan Tugas Penanganan COVID-19, 2020). Di sebagian besar negara, penurunan kasus dilakukan dengan karantina nasional, langkah-langkah jarak sosial, cuci tangan, penutupan sekolah, masker mulut atau kegiatan lainnya (Leung et al., 2020). Langkah-langkah tersebut berhasil meratakan kurva dan mengurangi arus masuk pasien ke rumah sakit sehingga mengurangi tekanan pada kapasitas rumah sakit.

Penelitian ini menunjukkan RSUD dr.Wahidin Sudiro Husodo Kota Mojokerto telah siap menghadapi pandemi COVID-19 yang ditunjukan dengan pengalihfungsian beberapa ruang yang dikhususkan untuk pasien COVID-19 dimulai pada bulan April 2020 hingga Mei 2021. Pada bulan Mei 2021 di RSUD dr. Wahidin Sudiro Husodo Kota Mojokerto terjadi penambahan jumlah tempat tidur untuk pasien COVID-19 sedangkan jumlah kunjungan pasien sudah menurun sejak bulan Maret 2021, namun hal tersebut dilakukan untuk mengantisipasi lonjakan COVID-19 pasca libur lebaran seperti tahun 2020. Penambahan jumlah tempat tidur secara tidak langsung mempengaruhi efisiensi manajemen pelayanan rawat inap untuk pasien COVID-19 dan penggunaan tempat tidur. Salah satu indikator pelayanan rawat inap yang menunjukan efisiensi penggunaan tempat tidur yaitu BOR (Bed Occupancy Ratio), apabila nilai BOR tidak sesuai dengan standar ideal menunjukan bahwa kurangnya optimalisasi penggunaan tempat tidur seperti alokasi tempat tidur dan penempatan tempat tidur oleh pihak manajemen yang dapat mengakibatakan 
terjadinya pemakaian tempat tidur yang overload atau tempat tidur yang tidak terpakai (Pecoraro et al., 2015).

Sehingga perlu adanya keseimbangan antara memesan dan menyediakan jumlah tempat tidur untuk kasus COVID-19 yang cukup untuk perawatan rutin dan tidak dapat ditunda.Untuk mencapai keseimbangan tersebut, model prediktif dapat dilakukan, tidak hanya untuk memprediksi jumlah tempat tidur yang dibutuhkan yang harus dialokasikan untuk pandemi, tetapi juga untuk menginformasikan rumah sakit tentang penyediaan peralatan yang tepat dan pelatihan petugas kesehatan yang memadai untuk kebutuhan spesifik (Jansson, Liao dan Rello, 2020).

Prediksi kebutuhan tempat tidur tersebut dilakukan dengan membandingkan jumlah tempat tidur terakhir di RSUD dr. Wahidin Sudirohusodo pada bulan Mei 2021 dan jumlah tempat tidur tertinggi yang tersedia untuk pasien COVID-19. Hasil prediksi menunjukan bahwa RSUD Dr. Wahidin Sudiro Husodo Kota Mojokerto kelebihan mengalokasikan tempat tidur khusus pasien COVID-19. Kelebihan tempat tidur yang tidak dilakukan pendayagunaan dengan baik akan berdampak pada pemborosan biaya perawatan tempat tidur karena tempat tidur banyak yang tidak terpakai namun tetap digunakan untuk ruangan pasien COVID-19, sebaiknya jika kasus menurun tempat tidur bisa dialihfungsikan untuk pasien non COVID19 tetapi sebelumnya harus dilakuakan sterilisasi.

Analisis prediksi yang disajikan dapat digunakan sebagai dasar rencana kesiapsiagaan rumah sakit jika terjadi kemungkinan pandemi lain di masa depan karena dapat menyoroti hambatan struktural dan/atau fasilitas sistem kesehatan nasional (Griffin et al., 2020).
Pengelolaan sumber daya kesehatan dengan cepat dan efisien tidak hanya terbatas pada penyediaan fasilitas kesehatan seperti tempat tidur dan peralatan lain, namun juga perlu mempertimbangkan ketersediaan tenaga profesional kesehatan untuk mencegah kelebihan beban dan kejenuhan. Hal ini sangat penting bagi rumah sakit memiliki jumlah tempat tidur yang tersedia sedikit atau penuh pada hari-hari pertama epidemi namun tidak melakukan pengadaan, kekurangan profesional kesehatan (menghadapi beban kerja yang tinggi, stres kerja, tekanan waktu, dll) dan dukungan organisasi yang terbatas (Morgantini et al., 2020; Pecoraro, Luzi dan Clemente, 2021). Untuk itu, rumah sakit perlu melakukan analisis kapasitas dan efisiensi dalam pengelolaan komponen strukturalnya sebelum terjadi kedaruratan (Pecoraro, Clemente dan Luzi, 2020). COVID-19 terbukti menekan sumber daya rumah sakit dan banyak negara telah diproyeksikan mengalami kekurangan sumberdaya perawatan klinis karena masuknya pasien COVID-19 dengan cepat (Moiseev et al., 2021). Beban kerja tenaga kesehatan seperti perawat meningkat selama pandemi dikarenakan ketergantungan pasien terhadap tenaga kesehatan semakin tinggi, dimana 1 orang perawat merawat 1 pasien dan maksimal merawat 2 pasien. RSUD dr. Wahidin Sudirohusodo melakukan perekrutan tenaga kesehatan pada bulan Januari 2021. Selain tenaga perawat, penelitian sebelumnya juga menemukan perlunya rumah sakit memiliki tenaga terapis pernapasan karena terbukti sebagai faktor yang mempengaruhi kemampuan rumah sakit memberikan memberikan pelayanan tepat guna selama pandemi (Kobokovich, 2020). Dampak dari COVID-19 pada sistem rumah sakit akan menimbulkan masalah yang lebih kompleks jika manajemen rumah sakit 
tidak mempertimbangkan beban populasi pasien lainnya. Sehingga rumah sakit perlu mempertimbangkan strategi kombinasi penyelesaian berdasarkan ketersediaan sumber daya kesehatan yang memadai dan memaksimalkan kemampuan rumah sakit meningkatkan kualitas perawatan yang diberikan kepada pasien COVID dan nonCOVID.

\section{SIMPULAN}

Kebutuhan tempat tidur pasien COVID-19 di RSUD dr. Wahidin Sudiro Husodo Mojokerto periode Juni 2021 - Juli 2022 masih dibawah jumlah tempat tidur yang telah dialokasikan manajemen rumah sakit untuk penyelenggaraan pelayanan COVID-19. Perlu dilakukan upaya peninjuan pengadaan dan penempatan tempat tidur agar tempat tidur yang tersedia memiliki nilai tepat guna. Rumah sakit dapat mempertimbangkan pengadaan tenaga kesehatan seperti perawat dan tenaga terapis pernapasan untuk meningkatkan pelayanan selama masa pandemi dan dimasa yang akan datang.

\section{UCAPAN TERIMA KASIH}

Penulis mengucapakan terima kasih kepada manajemen RSUD dr. Wahidin Sudiro Husodo Kota Mojokerto yang telah memberikan izin mengakses dan menggunakan data pelayanan pasien COVID-19 sebagai bahan penelitian.

\section{DAFTAR RUJUKAN}

Bloom, J. A., Foroutanjazi, S. dan Chatterjee, A. (2020) "The Impact of Hospital Bed Density on the COVID-19 Case Fatality Rate in the United States," American Surgeon, 86(7), hal. 746-747. doi: $10.1177 / 0003134820939909$.

Griffin, K. M. et al. (2020) "Hospital preparedness for COVID-19: A practical guide from a critical care perspective," American Journal of Respiratory and Critical Care Medicine, 201(11), hal. 1337-1344. doi: 10.1164/rccm.202004-1037CP.

Han, B., Chen, X. dan Li, Q. (2018) "Application of case mix index in the allocation of nursing human resources," Journal of Nursing Management, 26(6), hal. 647-652. doi: 10.1111/jonm.12593.

Hashjin, A. A. et al. (2014) "Using quality measures for quality improvement: The perspective of hospital staff," PLoS ONE, 9(1). doi: 10.1371/journal.pone.0086014.

Iftimie, S. et al. (2021) "First and second waves of coronavirus disease-19: A comparative study in hospitalized patients in Reus, Spain," PLOS ONE, 16(3 March 2021), hal. 1-13. doi: 10.1371/journal.pone.0248029.

Jansson, M., Liao, X. dan Rello, J. (2020) "Strengthening ICU health security for a coronavirus epidemic," Intensive and Critical Care Nursing. Elsevier Ltd, 57(xxxx), hal. 102812. doi: 10.1016/j.iccn.2020.102812.

Kobokovich, A. (2020) Ventilator Stockpiling and Availability in the US. Tersedia pada: https://www.centerforhealthsecurity .org/resources/COVID-19/COVID19-fact-sheets/200214VentilatorAvailability-factsheet.pdf.

Kuntz, L., Scholtes, S. dan Vera, A. (2007) "Incorporating efficiency in hospital-capacity planning in Germany," European Journal of Health Economics, 8(3), hal. 213223. doi: 10.1007/s10198-0060021-6. 
Leung, K. et al. (2020) "First-wave COVID-19 transmissibility and severity in China outside Hubei after control measures, and second-wave scenario planning: a modelling impact assessment," The Lancet. Elsevier Ltd, 395(10233), hal. 13821393. doi: 10.1016/S01406736(20)30746-7.

Levaggi, R. dan Montefiori, M. (2014) "Health Care Provision and Patient Mobility," Developments in health economics and public policy, 12, hal. x. doi: 10.1007/978-88-470-5480-6.

Litvak, N. et al. (2008) "Managing the overflow of intensive care patients," European Journal of Operational Research, 185(3), hal. 998-1010. doi: 10.1016/j.ejor.2006.08.021.

Lolita, S. (2016) Analisis Kebutuhan Tempat Tidur Tiap Kelas di Unit Rawat Inap Rumah Sakit Djatiroto Kabupaten Lumajang, UNIVERSITAS JEMBER. UNIVERSITAS JEMBER.

Moiseev, S. et al. (2021) "Outcomes of intensive care unit patients with COVID-19: a nationwide analysis in Russia," Anaesthesia, 76(S3), hal. 11-12. doi: 10.1111/anae.15265.

Morgantini, L. A. et al. (2020) "Factors contributing to healthcare professional burnout during the COVID-19 pandemic: A rapid turnaround global survey," PLoS ONE, 15(9 September), hal. 1-11. doi: 10.1371/journal.pone.0238217.

Pecoraro, F. et al. (2015) “A methodology of healthcare quality measurement: A case study," Journal of Physics: Conference Series, 588(1), hal. 0-5. doi: $10.1088 / 1742-$ 6596/588/1/012027.
Pecoraro, F. et al. (2016) "Assessing the performance of health units using a mix of efficiency indicators," 2015 E-Health and Bioengineering Conference, EHB 2015, hal. 2-5. doi: 10.1109/EHB.2015.7391430.

Pecoraro, F., Clemente, F. dan Luzi, D. (2020) "The efficiency in the ordinary hospital bed management in Italy: An in-depth analysis of intensive care unit in the areas affected by COVID-19 before the outbreak," PLoS ONE, 15(9 September), hal. 1-15. doi: 10.1371/journal.pone.0239249.

Pecoraro, F., Luzi, D. dan Clemente, F. (2021) "Analysis of the different approaches adopted in the italian regions to care for patients affected by COVID-19," International Journal of Environmental Research and Public Health, 18(3), hal. 1-15. doi: 10.3390/ijerph18030848.

Peters, D. H. et al. (2008) "Poverty and access to health care in developing countries," Annals of the New York Academy of Sciences, 1136, hal. 161-171.

doi: 10.1196/annals.1425.011.

Provinsi Jawa Timur (2020) Jatim Tanggap COVID-19. Tersedia pada: https://infocovid19.jatimprov.go.id/ (Diakses: 10 Februari 2020).

Ravaghi, H. et al. (2020) "Models and methods for determining the optimal number of beds in hospitals and regions: A systematic scoping review," BMC Health Services Research. BMC Health Services Research, 20(1), hal. 1-13. doi: 10.1186/s12913-020-5023-Z.

Remuzzi, A. dan Remuzzi, G. (2020) "COVID-19 and Italy: what next?," The Lancet. Elsevier Ltd, 
395(10231), hal. 1225-1228. doi: 10.1016/S0140-6736(20)30627-9.

RI, K. (2021) "Surat Edaran Nomor HK.02.01/MENKES/2/2021

Tentang Peningkatan Kapasitas Perawatan Pasien Coronavirus Disease 2019 (COVID-19) Pada Rumah Sakit Penyelenggara Pelayanan Coronavirus Disease 2019 (COVID-19) di Lingkungan Kementerian Kesehatan.”

Sabarguna, B. S. (2008) Pemasaran Pelayanan Rumah Sakit. Jakarta: Sagung Seto.

Satuan Tugas Penanganan COVID-19 (2020) Data Sebaran COVID-19. Tersedia pada: https://covid19.go.id/ (Diakses: 10 Februari 2020).

Sidjabat, F. N. dan Arthameivia, R. E. (2021) "Evaluasi Penyelenggaraan Surveilans COVID-19 di UPTD Puskesmas Pare Kabupaten Kediri," Journal of Health Epidemiology and Communicable Diseases, 7(1), hal. 1-9. doi: https://dx.doi.org/10.22435/jhecds.v 7 il. 4819 .

Suara.com (2020) Ahli: Ada Dua Faktor yang Bisa Jadi Penyebab Kasus
COVID-19 Tinggi di Jatim, 13 Juli 2020.

Tortorella, F. et al. (2013) "Improving bed turnover time with a bed management system," Journal of Nursing Administration, 43(1), hal. 37-43. doi: 10.1097/NNA.0b013e3182785fe7.

WHO Regional Office for Europe (2020) "Hospital Readiness Checklist for COVID-19," World Health Organization, Interim ve, hal. 1-37.

Woolf, S. H. et al. (2020) "Excess Deaths from COVID-19 and Other Causes, March-July 2020," JAMA - Journal of the American Medical Association, 324(15), hal. 15621564. doi: 10.1001/jama.2020.19545.

Xu, S. dan Li, Y. (2020) "Beware of the second wave of COVID-19," Lancet, (395), hal. 1321-1322.

Yi, P. et al. (2010) "Hospital capacity planning for disaster emergency management," Socio-Economic Planning Sciences. Elsevier Ltd, 44(3), hal. 151-160. doi: 10.1016/j.seps.2009.11.002. 